\title{
A school without railings: rural backgrounds, social medicine, and the circulation of public health material in Colombia, 1930-1946
}

\section{Uma escola não cercada: experiência rural, medicina social e circulação de material de saúde pública na Colômbia, 1930-1946}

\author{
Natalia Botero-Tovar \\ 'Historian, Medical Doctor, Universidad de los Andes. \\ Bogotá - Cundinamarca - Colombia \\ orcid.org/0000-0001-7664-5452 \\ n.botero22@gmail.com
}

Received on 21 Oct. 2019.

Approved on 14 Apr. 2020.
BOTERO-TOVAR, Natalia. A school without railings: rural backgrounds, social medicine, and the circulation of public health material in Colombia, 1930-1946. História, Ciências, SaúdeManguinhos, Rio de Janeiro, v.28, n.3, jul.-set. 2021, p.795-808.

\begin{abstract}
Ambitious state hygiene education projects designed during liberal governments in Colombia (1930-1946) faced not just the poverty of rural populations, but also the reluctance of local political forces. I analyze hygiene education programs during the first two liberal governments of the Liberal Republic. I argue that public health programs did not reach their audience due to local clientelism and political corruption. The sources of this article come mainly from Colombia's Ministry of Education reports and cultural magazines. The education sector also had health-related responsibilities and developed assessments of local needs, which contributed to public health programs. Latin America's public health historiography could be enriched by exploring failures in the implementation of projects in the history of social medicine.
\end{abstract}

Keywords: public health; social medicine; history.

Resumo

Projetos governamentais de educação em saúde propostos por governos liberais da Colômbia (1930-1946) enfrentaram não apenas a pobreza das populações rurais, mas também a relutância de forças políticas. Analiso os programas de educação em saúde durante os dois primeiros governos da República Liberal. Argumento que os programas de saúde pública não alcançaram o público alvo por causa de clientelismo local e corrupção política. As fontes deste artigo foram, principalmente, relatórios do Ministério da Educação da Colômbia e revistas culturais. O setor da edução teve responsabilidades relacionadas à saúde e desenvolveu avaliações das necessidades locais, que contribuíram para programas de saúde pública. A historiografia da saúde pública na América Latina poderia se beneficiar se explorasse as falhas na implementação de projetos de medicina social.

Palavras-chave: saúde pública; medicina social; história. 
$I^{n}$ n 1934, Daniel Samper Ortega, director of Colombia's National Library, described his journey to the department of Boyacá, a region north of the capital city, Bogotá. He was impressed by the welcome he received from Boyacá's education directors and regional elite. His mission was to develop and test a film education project with equipment that the Ministry of Education had recently acquired. This took place in "the wonderful land where Colombia's independence battles were fought, and where the first battle to liberate the consciousness of peasants has been fought as well" as Samper Ortega (1934, p.146) wrote to his friend Luis López de Mesa, a medical doctor who was by then the country's minister for Education. Samper Ortega went on to praise the diplomatic attitude of the doctors in strategic positions in the Ministry of Education, though he also called for there to be accountability for their actions. He described the case of a rural school, a three-story building that lacked railings. Shocked at the obvious health hazards posed by this, Samper Ortega complained to his friend that when he asked for the reasons for what he described as a "barbarous" situation, one of the people in charge of the school answered: "We haven't had a casualty yet. Certainty of falling is a better protection for the children than a bunch of rods tied up between columns, which would allow them to fool around" (Samper, 1934, p.148). Samper Ortega then contacted Boyacá's departmental director, a "medical doctor and parent," to ask him to "close down this school until railings are installed," and declared that he would "see how they take money from where they do not have it" (p.149). Samper Ortega could have been referring to the requirement that Colombian municipal councils covered the costs of school infrastructure or he could have been highlighting landowners' obligations to provide a free and appropriate school establishment in rural areas where more than twenty school-age children dwelled.

The ambitious Colombian Ministry of Education projects designed by liberal governments between 1930-1946, in which Daniel Samper Ortega was involved, faced more than the extreme poverty endemic in most of the country's rural societies, but also resistance to change in municipalities where the dynamics of local power contributed enormously to the perpetuation of inequality and poverty. It is interesting to note how the medical doctors that held leadership positions at that time dealt with the "social problem" from a different perspective. While they performed a bureaucratic role, they also shared responsibility when they witnessed the kind of political corruption Samper Ortega warned of.

Daniel Samper Ortega's accusation summarizes the main argument of this article: that the causes of diseases, poverty, and illiteracy were directly linked to the dynamics of municipal corruption and a bureaucratic framework that inhibited the implementation of state-driven rural hygiene education campaigns. This article focuses on the first two consecutive liberal governments, from 1930 to 1938, from a longer period known as the "Liberal Republic" (1930-1946), and their hygiene education policies. This period reveals a rich history of rural hygiene education in Colombia, analyzed notably in the context that is described as the "first wave" of Latin American social medicine (Carter, 2018; Birn, Muntaner, 2019). By 1930, social medicine was an extension of hygiene and a means to integrate national societies (Cueto, Palmer, 2015). Besides, the context of the agrarian reform led by President Alfonso López Pumarejo and other social reforms introduced by 
the Liberal party quickened the pace of cultural programs designed to boost health and education and to strengthen Colombia's national identity (Muñoz, 2009; Jalil, 2015).

This research aims to analyze some state-orchestrated public health policies that failed to disseminate material for hygiene education to el pueblo, or the target population, because of corruption within municipalities. In spite of stereotypical misconceptions of the poor and medical recommendations that did not match the reality of life in rural areas of the country, this barrier in the implementation of public health policies was inherent to the context in which medical endeavors were made in the countryside during the 1930s (Carrillo, 2005; Soto-Laveaga, 2013; Valderrama, 2010; Jalil, 2015).

I argue that clientelism impacted the complexities of opposition parties, corruption, and manipulation of public positions in the municipalities, which is crucial for the analysis of the history of public health. The structure of politics in rural societies during the 1930s constituted an obstacle for the successful execution of hygiene and education policies and limited the circulation of materials for public health education, like handbooks on healthcare and prevention, agriculture, and pedagogy, among others. Writers, educators, and medical doctors from the Ministry of Education developed wide-scale campaigns that clashed with regional corruption barriers that have hitherto not been explored in the history of medicine. This research focuses on how hygiene education campaigns headed by the Ministry of Education affected the implementation of state-driven policies, which in turn faced the challenges of understanding and surpassing the local dynamics of power that fueled social inequality.

Beyond a limited appreciation of the ways of life in the country's underdeveloped regions, the Colombian rural campaigns show the contradiction between politicians' fascination with regional differences and their difficulty in coordinating with regional political power (Robledo, 1946; Muñoz, 2009; Jalil, 2019). In most countries, the context of social medicine in the international health activities of the 1930s was comprised of different approaches to tackle the social and economic factors affecting diseases, while largely overlooking local dynamics (Packard, 2016). One documented exception is the case of Peru's public health programs in rural Puno. This case exemplifies the conditions that served to surpass cultural misunderstandings and favor health outcomes in the interaction between public health methods and rural communities during the 1930s, such as peace between indigenous communities and landowners, hygiene and education promotion, and identity built from indigenismo (Cueto, 1997). In a recent article, historian Hanni Jalil (2019) discusses how the reproduction of rural stereotypes in the magazine Salud y Sanidad, published by the National Department of Hygiene of Colombia, limited the effectiveness of a public health model by failing to address social inequalities.

In the first section of this article, the interdependence of hygiene and education are examined from the point of view of the organization of the Ministry of Education, as hygiene education was not exclusive to the health sector. This is complemented by a discussion of the multiple forms of health services in Colombia, especially before 1938, when the Ministry of Labor, Hygiene, and Social Protection was established (Hernández, 2000). The Liberal Republic ruled at a time considered to be a breaking point from unilateral orientations of hygiene campaigns by conservative governments, when hygiene "was 
accepted as an indicator of civilization, but not aided as a state policy" (Robledo, 1946, p.106). Contradictions are then highlighted in the implementation of cultural policies, which exposed tensions with the main actors the liberals wanted to empower as the carriers of education and knowledge: schoolteachers.

In the second section, I analyze the challenges in the implementation of educational campaigns, including hygiene education. In her historiography of public health in Colombia, Hanni Jalil studies the challenges that faced public health programs and hygiene campaigns during the Liberal Republic, like scarce fiscal resources and limited personnel to staff newly created rural commissions and sanitary units (Jalil, 2015). The sources I explore show that these resources were embezzled and did not reach the target population, and that political clientelism was also a challenge for implementation. Some studies in Colombia, such as Leal and Dávila's (2010), identify political clientelism with the lack of institutional presence, also fueled by a bipartisan background. They define this problem from the perspective of the manipulation of public positions and provision of personal favors through state resources. As historian José Manuel Cerdas (2014, p.312) argues, clientelism - political machine, clientage, or clientship - is rooted in "the exchange of favors between two actors with unequal access to power and resources." In the history of Latin America, clientelism has been studied as a widespread political dynamic in rural societies in the nineteenth and twentieth centuries. Known more widely as caciquismo, it has been studied in Mexico during the Porfiriato, with the local varieties of rural patrons going by different names, such as cacique and gamonal in Colombia and Costa Rica, and coronel in Brazil (Cerdas, 2014). The inclusion of this dynamic adds a new dimension to any analysis of the history of public health.

\section{The burden of health in the crusade for education}

Scholars such as Mary Kay Vaughan (1997) have analyzed the role of rural teachers and schools as central state policymakers in Mexico during the 1930s and 1940s crusade for education. As she argues, during these decades, especially with the cultural program known as "socialist education" introduced by President Lázaro Cárdenas (1934-1940), teachers were key political actors in negotiations between state and peasantry, and schools became a powerful political arena. In the political agenda of rural hygiene in Mexico, schoolteachers were valued for their capacity to spread hygiene initiatives and education in the hope of improving peasants' habits. The rural newspaper El Sembrador and the publication El Maestro Rural targeted schoolteachers as promoters of public health, along with health professionals, publishing illustrations that "reinforced the value of school and the heroic role of the rural schoolteacher" (Gudiño, 2008, p.78). In Colombia, historian Renán Silva (2006) argues that schoolteachers were a central element in the liberal projects of cultural diffusion, and that they themselves were passionate about fulfilling the government projects.

The liberal politicians in Colombia in the early 1930s also had an education program in mind, but to fulfill it they had to overcome a major barrier: a shortage of teachers. In 1934, the physician Jaime Jaramillo Arango, dean of the National Faculty of Medicine and minister for Education, estimated that 24,000 teachers were needed to fill primary school 
vacancies (Jaramillo, 1934). According to the 1930 census, primary school teaching was mainly a female profession. The ratio between urban female and male teachers was nearly $2: 1$, while there was an equal proportion of female teachers with and without a degree. However, in rural parts teachers were mostly women. Of the total of 4,311 rural teachers, 3,884 were women, 3,592 of whom did not have higher education (Herrán, 1931). The 1930s education program in Colombia targeted primarily rural primary schools and teachers, most of whom were women with no university education.

Besides the shortage of teachers and the urge to promote teachers' education, statesmen from the Ministry of Education were shocked by the burden of health administration. Mario Hernández has discussed the role of modernization taken on by hygienists, who worked from a different perspective of charity or private health services (Hernández, 2000). Hygienists had their own niche inside the executive state apparatus and were deployed to the Ministry of Public Instruction. However, in 1927, the Colombian Congress ruled an administrative separation between health and education and the Ministry of Public Instruction and Sanitation was dissolved. The Ministry of Education was restructured, and responsibility for leprosaria, hygiene, and sanitation were assigned to the National Leprosarium Direction and the National Hygiene Direction, respectively. Health remained an economic burden for the education sector. In 1930, 49\% of the Ministry of Education's entire budget was spent on leprosarium maintenance and ten percent was dedicated to "hygiene and sanitation." Less than five percent of the budget was allocated to "primary education" (Caycedo, 1931, p.131). The administrative division of health and education had two motives: to attract the attention of the executive branch to each of these sectors and to emphasize the importance of sanitary policy (Hernández, 2004).

Health as a policy remained on the liberal government's agenda as a key welfare program aligned with educational campaigns with a more optimistic tone than previous conservative public health policies. "Hygiene must start at school," wrote an education minister in 1933, highlighting that roughly one third of applicants for mandatory military service had diseases that disabled them for this job, probably acquired at school (Carrizosa, 1933). Medical doctors and teachers were the cornerstones of hygiene education, and doctors aided the Ministry of Education in recognizing the challenges of primary schools on a larger national scale. The School Medicine and Physical Education division of the Ministry of Education was put in charge of overseeing the future "race" of Colombian workers and soldiers. Debates held about race in Colombia involved arguments by medical doctors like Jorge Bejarano, who supported the view of a strong people (or pueblo) that had to overcome environmental threats with hygiene measures (Muñoz, 2011). Liberal politicians explicitly continued reinforcing sanitation in Colombia's tropical highlands to enhance the productivity of the region's working-class population. In the 1930s, the liberals shifted the focus on eugenics to consider the social problems behind the "physiological" waste of the poor, in what historian Stefan Pohl-Valero (2014, p.466) depicts as the "energy-centric and racial perception on the 'social question.'"

Liberal intellectuals shared optimistic initiatives for social change but had to overcome barriers in the administration and implementation of their projects. One of these was the administrative separation between health and education. In the process, the blurred 
division between health and education, and the intention to tackle both as an explanation of Colombia's "backwardness," contributed to legitimize the medicalization of the state institution. By forging an alliance between medicine and schools, this initiative also enabled medical doctors who already occupied powerful positions in some departments to embark on a political career.

In 1934, when Jaime Jaramillo (1934, p.289) stated that "medicine is the ally of the school," he envisioned guaranteeing the permanent presence of a medical doctors in rural areas, rather than sporadic campaigns. This policy remained on paper because of the scarcity of health professionals and the uneven geographical distribution of the few medical doctors. It was evident that the shortage of doctors in rural areas of Colombia was a legitimate concern, as was the shortage of teachers. However, as historian Gabriela Soto-Laveaga (2013) argues about the medical services in post-revolutionary Mexico, the focus on the lack of physicians as the main factor of rural backwardness meant poverty was de-centered as the main cause of rural diseases. Colombia's rural hygiene and education policies developed heterogeneously, though they were applied in regions containing an abundance of medical doctors and schoolteachers and in ones with scarce professionals. This exposed the incapacity of the state institution to implement its own policies throughout the country, especially during a time when the centralization of state projects was perceived as a priority (Muñoz, 2009).

For example, a physician in the Department of Cundinamarca explained the mission of the school doctor, which "was not therapeutic, but preventive ... giving instructions to inspect schools, lecture children and parents, contact municipal authorities, and cooperate with teachers and [school] inspectors" (Rosales, 1934, p.178). Since doctors were also training teachers in hygiene education, cooperation went hand in hand with surveillance. In Boyacá, where doctors and teachers were not as scarce, medical authority over teachers turned into a mission to identify teachers as potential transmitters of diseases. More than 250 schoolteachers attended an informative and cultural program during their holidays, which included lectures about hygiene, psychology, biology, and agriculture, among others. The program provided the opportunity for medical doctors to ascertain whether the teachers may be carrying any diseases by giving them clinical examinations in order to "issue a health certificate ... and prevent teachers with contagious diseases from continuing at schools and putting children at risk" (Sánchez, 1934, p.122). Along with clinical details about vaccinations against typhoid fever and smallpox, this certificate also stated whether the schoolteachers were approved to continue in their profession.

The presence of the Ministry of Education's school doctors was weak in other regions of the country. Cundinamarca, Antioquia, and Boyacá were the three most populated departments of Colombia, according to a 1928 national census, with an estimated number of one doctor per every 3,500 inhabitants, one per every 3,000, and one per every 11,312, respectively. ${ }^{1}$ The Ministry of Education's school doctors policy during the 1930 s can be considered an attempt to improve those statistics.

However, departmental education directors wrote discouraging annual reports about the rules that remained in Bogota, but never became a local reality, like the school doctors policy. From the southern department of Nariño, which had never had a school doctor, 
Jorge Buendía (1934, p.210) complained about the "inexcusable void of the educational program". Through his official report, Buendía emphasized Nariño's commitment to maintaining hygiene initiatives with the Rockefeller Foundation's anti-hookworm campaign. In his report to the Ministry of Education, Buendía expressed his gratitude to the National Department of Hygiene for improving the school infrastructure with the provision of toilets, and for the municipal doctor, who "contributes to fill the gap of the school doctor" (p.222). This same director stated that Nariño gave 3,000 pesos every year to the Anti-Anemia Commission, approximately the same amount dedicated to scholarships for students "continuing education in this city [Pasto], Popayán, Bogotá, Quito, Milan, and Brussels" (p.221). Buendía challenged the scope of the Ministry of Education. What was a cause for regional pride - engagement with international health goals - was also the counterpart in the dialogue, showing the fragmentation and decoupling of regional, national, and international commitments towards eradication campaigns.

Another report on state education hygiene initiatives came from the Amazon Rainforest in 1934. The school inspector and priest Fray Gaspar Obispo (1934, p.49) highlighted his role in distributing copies of the free bi-monthly journal Salud $y$ Sanidad (Health and Sanitation) among teachers, local mayors, and municipal councils. From 1932 to 1942, the National Hygiene Department published this journal, which was funded by the Rockefeller Foundation's Hookworm Division. It served to promote government rural health programs with articles and advice on yellow fever, malaria, hookworm, alcoholism, tuberculosis, and venereal diseases. As Hanni Jalil (2019) argues, this journal reinforced stereotypes about Colombia's rural peasants and contradicted the state's rhetoric of inclusion.

Despite this, Fray Gaspar Obispo (1934) was eager to get more copies of Salud y Sanidad to distribute to teachers and other local readers and voiced this intentions in his report to the Ministry of Education. This case demonstrates how labeling it as an international health initiative, one that was promoted by the National Department of Hygiene, facilitated the circulation of this magazine. This public health material was politically neutral, which, in the context of the rivalries between the Liberal and the Conservative parties, who ruled during forty consecutive governments, was crucial for spreading the message to the countryside. This case also portrays the familiarity between this inspector, the municipal ruling class, and teachers from neglected regions such as the Amazon, which had been at the center of the Colombian government's interests during the war with Peru from 1932 to 1933. Outcomes were different for material prepared by medical doctors who were influential statesmen, envisioning cooperation between social medicine and rural community health care from within the political realm of the Ministry of Education.

\section{Reaching out to the countryside and the local dynamics of political power}

The implementation of educational, health, and cultural programs faced more challenges than those associated with a shortage of local staff (teachers and health professionals). They were also blocked by the misappropriation of resources. Luis López de Mesa, a medical doctor and minister of Education, was a liberal reformer who envisioned education as 
a way of encouraging Colombian workers and peasants to take care of their bodies and communities (Jalil, 2015). Years before occupying the position of minister of Education, López de Mesa presented arguments about Colombia's racial and geographical complexity, though still making some conceptual generalizations (Muñoz, 2011). López de Mesa was convinced that the educational void was a barrier to national progress, and during the Liberal Republic he held a strategic position.

Cultura Aldeana involved different state institutions in a bid to "recover [Colombia's] high intellectual prestige in the continent" (Samper, 1934, p.1). López de Mesa undertook the production of educational supplies both for export as a national product and for internal distribution. As he wrote, Cultura Aldeana would grant the Colombian peasant, "within the Republic's [impoverished] means, the greatest possible material wellbeing and spiritual dignity so that they may love the life they are lucky enough to have and live it with joy and gratitude" (López de Mesa, 1934, p.3). Besides the rhetoric of this determinist explanation of inequalities based on geographical, social, and racial factors, it allows for an exploration of President López Pumarejo's purpose in achieving the modernization and material wealth of the peasantry by means of culture.

School innovation relied upon a considerable budgetary boost for material supplies, ranging from 17,000 pesos, invested by the government in 1930, to 500,000 pesos, invested during López Pumarejo's government (Echandía, 1936). The implementation of the plan envisioned by López de Mesa implied the allocation of state resources to education, which received criticism from a divided elite. However, López de Mesa and the intellectuals that headed this campaign were successful in coordinating the institutional participation of different state entities in what today would be called a multisectoral intervention. This was achieved by writing handbooks for schoolteachers as the collection known as Biblioteca Aldeana, which were based on the municipalities' own assessments gathered in a cultural census run by the National Library.

Parallel to the outreach by the Colombian biomedical field to the countryside and early attempts to consolidate epidemiological research in Colombia, López de Mesa was concerned with medical geography and social medicine, and explored them within the scope of the cultural census (Estrada, 2004). Local mayors were in charge of answering questions and sending them back to the National Library. The scope of the census included inquiries about each municipality, including reports about local weather and the number of inhabitants. It also asked them to provide a broad assessment of their capacity to implement the educational campaigns, including specific details about improvements to electricity, classroom capacities, market days (for mass campaigns), the local press, the principal industries, agricultural specialties, and diseases that affected the local people, livestock, and crops. The cultural census included a blank space for the assessment of municipalities' needs, and many mayors reported a lack of radio, cinema, books, agricultural instruction, and medical doctors. Data collected through this census indicated that the most prevalent diseases in most of rural Colombia were tropical anemia, malaria, typhus, and tuberculosis (Samper, 1936). Accordingly, liberal intellectuals prioritized the diffusion of health-related educational material. However, the circulation of the material was hampered, resulting in the failure of the project, not to mention the fact that the medical advice failed to match the rural realities. 
Despite the provision of financial support and the attempt to meet local needs, Cultura Aldeana had poor results (Silva, 2012). The project continued after López de Mesa retired and Senderos magazine praised him for knowing "how to go down from the highest spheres of intellectual speculation, to the unbearable petty details of administrative [tasks]" (El ministro..., 1935, p.1). Data collected during the implementation of the project reveal that the poor results were closely related to the resistance of the local elites. One outcome of the cultural census's assessment was the circulation, via Biblioteca Aldeana, of public health material, such as handbooks about childcare, nutrition, prevention of dental, ear, nose, and throat diseases, and physical education (Sáenz, Saldarriaga, Ospina, 1997). The National Library distributed nearly 100,000 items in Biblioteca Aldeana in the country from 1935 to 1936 (Samper, 1936). At the same time, around 50,000 were circulated worldwide, most of them reaching the United States, Spain, and Argentina. A 1935 report records the national distribution of 5,555 handbooks on nociones de puericultura (childcare), and nearly 300 copies of Las 12 plagas mayores, which included topics like alcoholism, syphilis, cancer, snake bites, malaria, and tuberculosis, among others (Samper, 1936). However, the history of the circulation of this material demonstrates rivalries between bipartisan interests and the strong political affiliations that existed at the time.

Given this information, it seems it was the exception rather than the norm for schoolteachers to gain access to Biblioteca Aldeana. In 1937, a teacher wrote a letter to Daniel Samper Ortega, claiming that schools were not supplied with handbooks, hampering his work:

Despite my efforts ... there is a remarkable shortage of the handbooks that the schoolteachers are supposed to keep studying ... [They] are lost due to many environmental circumstances, mainly because of the incompetence of the ruling class in accustoming people to read, [and] the persecution and false prejudices, blocking [the liberal] regime, by Conservatism, or by the clergy (Estrada, 4 jul. 1937, p.257).

This accusation portrays the challenges facing the implementation of state policies, which, beyond a narrow understanding of local dynamics, was further complicated by the overwhelming resistance of regional circuits of power and bipartisan rivalry. Material rural improvement, such as technical agricultural knowledge, health care and public health initiatives, education, and local culture were impacted by a heavy partisan burden. During Alfonso López Pumarejo's government, the most radical reformist years of the Liberal Republic known as the "Revolution on the March," the alliance between the Catholic Church and the Conservative party constituted a major source of resistance to the changes the liberals were making to social institutions. For example, the Constitutional Reform of 1936 included the secularization of education, constituting an explicit threat to the Catholic Church and the traditional educational system (Arias, 2000). This context is integral in understanding the attempts of state-driven policies concerning rural improvement, hygiene education, and disease prevention, and the fierce opposition they inspired.

The liberal governments' projects brought into evidence regional fanaticisms that were materialized in the misuse of public resources. A letter from a school inspector in the Caldas Department warned of a potential conspiracy hatched by the Conservative party, mentioning that Centro Caldas "in fact, the center of the municipal Conservative committee ... has 
acquired some books from the Ministry [of Education] and a radio that they will use with the purpose of making their communications, which should be owned by the school" (transcribed by Zalamea, 1 feb. 1937). Radio was a key element in reaching the illiterate peasantry and also in spreading the liberal political agenda. For municipalities, radio was also a means of encouraging hygiene education, witnessed in the plea by the Magdalena Department for the liberal government to supply a radio station so that people could "pick up the instructive conferences given at the Liberal house, and be instructed in hygiene and sanitation, disciplines that are not taught either theoretically or empirically to these populations" (transcribed by Lleras, 18 mar. 1935). Possession of a radio station to broadcast communications triggered discussions among the Liberal and Conservative parties in Colombia.

Policies involving material improvements in rural parts exposed bipartisan competition in the municipalities, and ignited rumors about fierce resistance. For example, the Education minister read news about the intentions of the Conservative council to burn the Biblioteca Aldeana (Zuluaga, 22 may 1935). From Sasaima, in Cundinamarca, Daniel Samper Ortega received a letter from the local priest, advising him to include the clergy in the administration of Biblioteca Aldeana, claiming that "the priest has been cornered, when he is the one who works for the people's instruction and in favor of the preservation of precious objects" (López, 14 jan. 1935, p.279). Municipal councils were in charge of overseeing the distribution of Biblioteca Aldeana, but the priest warned Samper Ortega that they did not have the skills to accomplish this cultural task, writing that "municipal councils are [usually] made up of businessmen who only care about [monetary] gain, or in other cases by officials with little education, who govern by bossing others" (López, 14 jan. 1935, p.279). With this accusation, this local priest warned about the complexities of the social make-up of Colombian rural municipalities and the particularities of ruling them.

Historian Jorge Marquez Valderrama (2010) mentions the importance of gamonalismo in the medicalization of rural regions in the 1920s, and how this local power impeded some doctors from fulfilling their biomedical roles and put pressure on them to treat specific patients first. In that sense, rural contexts consisted of more than the dyadic relationship between doctors and patients, including the intermediaries (gamonales) that widened the asymmetry of the relationships that existed in the municipalities. Historian Gabriela SotoLaveaga (2013) explains the concept of the "contact zone," which reveals asymmetrical interactions between the young medical doctors reaching out to the countryside and their rural patients in post-revolutionary Mexico. Municipalities are propitious social spaces for expanding the concept of the contact zone and considering the complex asymmetries and circuits of influence, resistance, and opposition by other social actors in the history of public health. Taking a different angle than the biomedical, Colombian policy makers in the 1930s envisioned health as a state function, which brought them into conflict with the local regimes.

The liberal elite appreciated physicians' diplomatic role in implementing state-driven campaigns. Medical doctors occupied powerful political positions, and fleshed out authority, literacy, modernity, and political neutrality. For government officials, they were reliable, practical local actors that could help in implementing the Ministry of Education's policies. Medical doctors were also garnering political positions beyond biomedical or public health 
roles. Competition over public positions promoted anarchy inside the health and education institutions, which frustrated the leading liberal elite of the time.

This is exemplified in the case of a medical doctor who occupied a public position as director of an education department. In 1936, the Education Minister Dario Echandía denounced the chaos inside the National Hygiene Department. Echandía was concerned about the lack of technical knowledge about the hygiene campaigns of the people occupying municipal and departmental positions and the absence of articulation towards a common national project. To Echandía (1936, p.18), that was rooted in unequal local interests, where

each of the participants - nation, department, and municipality, private or semiofficial institutions - has a different program, [different] system of action, and a closed circuit bureaucracy, without an actual link to similar or identical services that other institutions offer ... departmental education directors, managers, businessmen, or politicians, occupy the leading positions in these campaigns, and their good intentions interfere with the lack of technical qualification that only specialized professionals or hygienists have.

What Echandía highlighted as a lack of technical knowledge had a deeper impact on local clientelistic relationships, where ambitions for power fueled quarrels over and the manipulation of public positions. State policies, including public health and rural hygiene campaigns, clashed with the bureaucratic framework within state institutions. As Echandía implies, these sanitary campaigns supplied political and financial security for those who ran them, and for those who gained employment as reciprocal favors. In his accusation, Echandía (1936, p.13) adds that liberals faced "the spectacle of a bureaucratic organization that survived the hegemonic [conservative] past which was far from a public service or the beginnings of a policy, but focused on the defense and assurance of a position ... in charge of certain people who, at expense of their rank, guaranteed a sort of internal monarchy."

Echandía also denounced the barriers restricting the implementation of government policies. Regarding school supplies, which represented the material wealth that liberals had promised to the Colombian countryside, Echandía (1936, p.37) emphasized that fifty percent of the entire budget for school materials was lost on the winding route from the ministry's central offices to rural schools. The supplies included notebooks, school books, magazines, ink, pens, chalk, paint for blackboards, maps, and school infographics with "a double function of embellish[ing] the gloomy schools and teaching lessons about hygiene, sports, agriculture etc." Echandía (1936, p.37-38) was astonished and frustrated, and argued that

while the Education Ministry distributed - though without respecting the equal proportions each department had as a right - school supplies to the directors of education departments in order to deliver them to schools, municipal authorities or school inspectors ... fifty percent of supplies destined to Colombian children were lost on the way, becoming public office notebooks, material for police records, [or] bargaining merchandise that finally reached the children's hands not as a free state service, but as a commodity bought at local stores, heaven knows by what extraordinary means. What happened to the school infographics [prepared by the Ministry], which did not reach the school walls, but embellished those of the private houses of the officials in charge of their control and distribution. 
For Echandía and other politicians at the time, this evidence of corruption portrayed a reprehensible system compared with the vision of the modern state the liberals had in mind. This accusation of Echandía's shows the shared accountability for resources, from the national to the municipal level. However, it was easier to attribute poverty to the social backwardness of the Colombian peasantry.

\section{Final considerations}

In Colombia, poverty and illiteracy were indelibly linked to corruption in local administrations, which jeopardized the implementation of state-driven rural hygiene education programs. During the Liberal Republic, doctors and state officials from the governments examined herein developed material intended for hygiene education, agricultural development, disease prevention, and health care, among others. However, this material represented a political ideology that clashed with the local ruling classes. During the 1930s, handbooks, magazines, radios, and even cinema equipment were highly politicized objects that failed to reach the target population through a state-driven program. When the history of public health in Colombia is studied, more attention should be directed towards how political corruption, embezzlement, and clientelism affected public health programs. This research aimed to contribute to the historiography of public health in Colombia, exploring some critical obstacles faced by Liberal reformers in their bid to expand modern public health services in the country. Tracing these local political barriers could be challenging but very rewarding, as they are key to examining the "first wave" of Latin American social medicine, which aimed for the integration of nations.

\section{ACKNOWLEDGMENTS}

I am very thankful to Pablo Gómez, who advised me and read and commented on the first drafts of this research, which I conducted at the Department of Medical History and Bioethics at the University of Wisconsin School of Medicine and Public Health. Stefan Pohl, Emilio Quevedo, and participants of the group of studies of sciences, technology and professions (GESCTP) gave me insightful comments during a seminar at Universidad del Rosario, Bogotá. The comments from the reviewers of this journal were very helpful.

\section{NOTE}

${ }^{1}$ Data from the 1928 census and medical doctors' registers collated by Jorge Márquez Valderrama (2010).

\section{REFERENCES}

ARIAS, Ricardo. Estado laico y catolicismo integral en Colombia: la reforma religiosa de López Pumarejo. Historia Critica, n.19, p.69-96, 2000.

BIRN, Anne-Emmanuelle; MUNTANER, Carles. Latin American social medicine across borders: South-South cooperation and the making of health solidarity. Global Public Health, v.14, n.67, p.817-834, 2019.
BUENDÍA, Jorge. Departamento de Nariño. In: Memoria del Ministerio de Educación Nacional al Congreso de 1934. Bogotá: Imprenta Nacional. p.205-225, 1934.

CARRILlO, Ana María. Salud pública y poder en México durante el Cardenismo, 1934-1940. Dynamis, v.25, p.145-178, 2005.

CARRIZOSA, Julio. Memoria del Ministro de Educación Nacional al Congreso de 1933. Bogotá: Editorial Cromos, 1933. 
CARTER, Eric. Social medicine and international expert networks in Latin America, 1930-1945. Global Public Health, v.14, n.6-7, p.791-802, 2018.

CAYCEDO, José. Informe de la sección tercera. In: Ministerio de Educación Nacional. Memoria del Ministerio de Educación Nacional al Congreso de 1931. Bogotá: Imprenta Nacional, 1931. p.13-134.

CERDAS, José Manuel. El clientelismo político: una revisión del concepto y sus usos. Anuario de Estudios Centroamericanos, Universidad de Costa Rica, v.40, n.0, p.311-338, 2014.

CUETO, Marcos. El regreso de las epidemias: salud y sociedad en el Perú del siglo XX. Lima: Instituto de Estudios Peruanos, 1997.

CUETO, Marcos; PALMER, Steven. Medicine and public health in Latin America: a history. New York: Cambridge University Press, 2015.

ECHANDÍA, Darío. Memoria que el Ministro de Educación Nacional presenta al Congreso en sus sesiones de 1936. Bogotá: Imprenta Nacional, 1936.

EL MINISTRO... El ministro López de Mesa. Senderos, v.4, n.18-19, p.1-3, 1935.

ESTRADA, Arnoldo. Letter to the Director of Colombia's National Library. Correspondencia Julio-Diciembre 1937 (Biblioteca Nacional, Jericó, Antioquia), 4 jul. 1937. In: Renán Silva. República liberal, intelectuales y cultura popular. Medellín: La Carreta Editores, 2012. p.257-258.

ESTRADA, Victoria. Comienzos de una epidemiologia de terreno en Colombia. In: Márquez, Jorge et al. Higienizar, medicar, gobernar: historia, medicina y sociedad en Colombia. Medellín: La Carreta Editores, 2004. p.127-158.

GUDIÑO, María Rosa. Educación higiénica y consejos de salud para campesinos en El Sembrador y El maestro rural, 1929-1934. In: Agostoni, Claudia. Curar, sanar y educar: enfermedad y sociedad en México, siglos XIX y $X X$. Ciudad de México: Universidad Nacional Autónoma de México, 2008. p.71-97.

HERNÁNDEZ, Mario. La fragmentación de la salud en Colombia y Argentina: una comparación socio-política, 1880-1950. Bogotá: Universidad Nacional de Colombia, 2004.

HERNÁNDEZ, Mario. La fractura originaria en la organización de los servicios de salud en Colombia, 1910-1946. Anuario Colombiano de Historia Social y de la Cultura, v.27, n.0, p.7-26, 2000.

HERRÁN, José. Clasificación del personal docente de la instrucción primaria oficial. In: Ministerio de Educación Nacional. Memoria del
Ministerio de Educación Nacional al Congreso de 1931. Bogotá: Imprenta Nacional, 1931. p.114115.

JALIL, Hanni. "A sick, weak, and ignorant people:" public health education and prevention in rural Colombia, 1930-1940. Bulletin of Latin American Research, v.38, n.1, p.19-34, 2019.

JALIL, Hanni. Curing a sick nation: public health and citizenship in Colombia 1930-1940. Dissertation (PhD in History) - University of California, Santa Barbara, 2015.

JARAMILLO, Jaime. Sobre educación nacional. Senderos, v.1, n.6, p.280-290, 1934.

LEAL, Francisco; DÁVILA, Andrés. Clientelismo: el sistema político y su expresión regional. Bogotá: Ediciones Uniandes, 2010.

LLERAS, Alberto. Letter to the minister of education. Correspondencia, 1936 (Biblioteca Nacional de Colombia, Bogotá), 18 mar. 1935.

LÓPEZ DE MESA, Luis. Estatuto de la aldea colombiana. Bogotá: Imprenta Nacional, 1934.

LÓPEZ, Marciano. Letter to director of Colombia's National Library. Correspondencia General, 1933-1936 (Biblioteca Nacional de Colombia, Sasaima, Cundinamarca). 14 jan. 1935.

MUÑOZ, Catalina. Los problemas de la raza en Colombia: más allá del problema racial: el determinismo geográfico y las "dolencias sociales." Bogotá: Editorial Universidad del Rosario, 2011.

MUÑOZ, Catalina. To Colombianize Colombia: cultural politics, modernization, and nationalism in Colombia, 1930-1946. Dissertation (PhD in Philosophy) - University of Pennsylvania, 2009.

OBISPO, Fray Gaspar. Vicariato Apostólico del Caquetá. In: Memoria del Ministerio de Educación Nacional al Congreso de 1934, t.2. Bogotá: Imprenta Nacional, 1934. p.5-27.

PACKARD, Randall. A history of global health: interventions into the lives of other peoples. Baltimore: Johns Hopkins University Press, 2016.

POHL-VALERO, Stefan. "La raza entra por la boca:" energy, diet, and eugenics in Colombia, 1890-1940. Hispanic American Historical Review, v.94, n.3 p.455-486, 2014.

ROBLEDO, Arturo. Una política sanitaria. In: Mendoza, Neira; Camacho, Angarita. El liberalismo en el gobierno. Bogotá: Editorial Minerva Ltda., 1946. p.93-121. 
ROSALES, José Miguel. Departamento de Cundinamarca. In: Ministerio de Educación Nacional. Memoria del Ministerio de Educación Nacional al Congreso de 1934. Bogotá: Imprenta Nacional, 1934. p.171-181.

SÁENZ, Javier; SALDARRIAGA, Óscar; OSPINA, Armando. Mirar la infancia: pedagogía, moral y modernidad en Colombia, 1903-1946. v.2. Medellín: Ediciones Foro Nacional por Colombia, 1997.

SÁNCHEZ, A.J. Departamento de Boyacá. In: Memoria del Ministerio de Educación Nacional al Congreso de 1934. Bogotá: Imprenta Nacional, 1934. p.121-129.

SAMPER, Daniel. Informe del director de la Biblioteca Nacional. In: Ministerio Nacional de Educación. Memoria que el Ministro de Educación Nacional presenta al Congreso en sus sesiones de 1936. Anexos II. Bogotá: Imprenta Nacional, 1936. p.33-71.

SAMPER, Daniel. Por tierras de Boyacá. Senderos, v.2, n.9, p.146-160, 1934.

SILVA, Renán. República liberal, intelectuales y cultura popular. Medellín: La Carreta Editores, 2012.
SILVA, Renán. Sociedades campesinas, transición social y cambio cultural en Colombia. Medellín: La Carreta Editores, 2006.

SOTO-LAVEAGA, Gabriela. Bringing the revolution to medical schools: social service and a rural emphasis in 1930s Mexico. Mexican Studies/ Estudios Mexicanos, v.29, n.2 p.397-427, 2013.

VALDERRAMA, Jorge Márquez. La extensión de la medicalización al mundo rural antioqueño a comienzos del siglo XX. In: Guerrero Barón, Javier; Wiesner Gracia, Luis; Martínez Martin, Abel Fernando (org.), Historia social y cultural de la salud y la medicina en Colombia, siglos XVI-XX. Medellín: UPTC; La Carreta Editores, 2010. p.241-259.

VAUGHAN, Mary Kay. Cultural politics in revolution: teachers, peasants, and schools in Mexico, 1930-1940. Tucson: The University of Arizona Press, 1997.

ZALAMEA, Jorge. Letter to the director of National Library. Asuntos Varios, 1937 (Biblioteca Nacional de Colombia, Bogotá), 1 feb. 1937.

ZULUAGA, Carlos. Letter to the minister of education. Correspondencia, 1936 (Biblioteca Nacional de Colombia, San Roque, Antioquia), 22 may 1935.

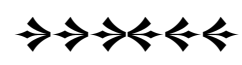

